ISSN 1507-3858

e-ISSN 2450-0003

\title{
Jacek Zasada
}

Wroclaw University of Economics and Business

e-mail: jacek.zasada@ue.wroc.pl

ORCID: 0000-0002-8993-9414

\section{INTEGRATION OF THE PRODUCTION PLANNING AND EXECUTION PROCESS IN ENTERPRISE MANAGEMENT IT SYSTEMS \\ INTEGRACJA PROCESU PLANOWANIA \\ I REALIZACJI PRODUKCJI \\ W INFORMATYCZNYCH SYSTEMACH \\ ZARZĄDZANIA PRZEDSIECBIORSTWEM}

DOI: 10.15611/ie.2021.2.06

JEL Classification: M11, M15

(C) 2021 Jacek Zasada

This work is licensed under the Creative Commons Attribution-ShareAlike 4.0 International License. To view a copy of this license, visit http://creativecommons.org/licenses/by-sa/4.0/

Quote as: Zasada, J. (2021). Integration of the production planning and execution process in enterprise management IT systems. Business Informatics, (2).

\begin{abstract}
Nowadays, managers of manufacturing companies are facing more and more difficult decision-making problems to resolve. Fluctuations in demand and constantly growing markets place many requirements for planners to create a correct production schedule. Thanks to technological development it is possible to use systems supporting decision-making. However, not all systems work properly together. An example of problems with system integration is the implementation of a production monitoring system (MES) into an existing Enterprise Resource Planning(ERP) class system. This article aimed to show the use of the basic functions contained in the ERP system as part of the functions of the MES system. By integrating the ERP system with a mobile application, it becomes possible to obtain the basic functionalities of the MES system, i.e. monitoring of current production and confirmation of yield at the workplace. The article contains a short theoretical introduction regarding production schedule planning and the functions of ERP and MES class systems. The empirical part shows the diagnosed problems of the production company and an example of implementing an original solution, and is summed up with conclusions and guidelines for further stages of research.
\end{abstract}

Keywords: ERP system, MES, Supply Chain Management, production planning, logistics. 


\begin{abstract}
Streszczenie: W obecnych czasach menedżerowie przedsiębiorstw produkcyjnych stają przed coraz cięższymi problemami decyzyjnymi. Wahania popytu oraz stale rozwijające się rynki stawiają przed planistami wiele wymagań dotyczących utworzenia poprawnego harmonogramu produkcji. Dzięki rozwojowi technologicznemu możliwe jest korzystanie z systemów wspierających podejmowanie decyzji. Jednakże nie wszystkie systemy prawidłowo współpracują ze sobą. Przykładem problemów z integracją systemów jest wdrożenie systemu monitorującego produkcję (MES) do istniejącego systemu klasy ERP. Ten artykuł ma na celu pokazanie wykorzystania podstawowych funkcji zawartych w systemie klasy ERP jako części funkcji systemu MES. Poprzez integrację systemu ERP z aplikacją mobilną możliwe staje się uzyskanie podstawowych funkcjonalności systemu MES, czyli monitorowania bieżącej produkcji oraz potwierdzania uzysku na stanowisku roboczym. Artykuł zawiera krótki wstęp teoretyczny dotyczący ustalania harmonogramu produkcji oraz przedstawienie funkcji systemów klasy ERP oraz MES. Część praktyczna pokazuje zdiagnozowane problemy przedsiębiorstwa produkcyjnego oraz przykład wdrożenia autorskiego rozwiązania. Całość podsumowana jest wnioskami oraz wytycznymi na dalsze etapy badań.
\end{abstract}

Słowa kluczowe: system klasy ERP, MES, zarządzanie łańcuchem dostaw, planowanie produkcji, logistyka.

\title{
1. Introduction
}

Running a business is an extremely difficult task, which is associated with a great responsibility for the functioning of the organization. Entrepreneurs are required to know the processes that are taking place in their organizations. Improving them brings many benefits - starting from shortening the process time and enhancing quality, ending with the most important factor - reducing the cost of doing business.

Taking care of the machinery and equipment is another important aspect. Each failure of a machine generates costs associated with its repair. Sometimes they also cause production to stop, which, in addition to having to repair, also generates costs of production downtime. Any stoppage of the production process or its disruption places a heavy burden on the persons responsible for plant maintenance.

This work is a case study regarding implementing the solution for problems related to the administrative organization of production processes. The presented author's solution is to largely streamline the processes, allowing the company to achieve the aforementioned benefits from the improvement the main processes of the organization. This article shows how to use the basic functions of ERP systems as functions of the Manufacturing Execution System. The theoretical part of the work was prepared based on the analysis of literature in the field of logistics and production management, as well as publications related to information systems supporting decision-making in the field of production management. 


\section{Production planning as a key aspect of business management}

Planning in production companies is one of the most important areas of activity in companies. First of all, planning is the primary management function, so it is crucial that this phase is carried out properly. During planning, entrepreneurs first set the organization's goals and try to answer the question of what means achieve them.

The planning phase therefore goes through several stages (Hadaś, Fertsch, \& Cyplik, 2012, p. 8):

1) determination of the company's goals,

2) analysis of the internal and external factors affecting the implementation of the goal,

3) planning measures and ways to achieve the goal,

4) construction of the implementation schedule, which includes the division into tasks and other operations,

5) making a decision on implementing the plan.

There are also hierarchical relationships between plans in the organization, primarily based on the time horizon of the plan's validity. The relevance of documents increases in direct proportion to the duration of the horizon - the longer it is, the more important the plan. There are three basic types of planning based on time horizon - strategic, tactical and operational planning.

The central link in production planning is the Master Production Schedule (MPS), which contains the dates of production launch and production lot sizes. The main task of MPS is to balance the material needs and production capacity of the company through the most effective use of the organization's resources and the even load on workstations, ensuring a set level of customer service, thus making products with the lowest possible use of resources while maximizing the achieved profit (Śliwczyński, Koliński, \& Andrzejczyk, 2014). There are three ways to create a main production schedule (Hadaś et al., 2012):

1) production to the warehouse-MPS is developed generally, without matching products to individual customers, the schedule is prepared on the basis of sales forecasts,

2) production to order - scheduling is carried out for a specific customer, and the lot size is adapted to the customer's order,

3) mixed option - MPS is developed using sales forecasts and orders from customers.

\section{Comparison of ERP and MES class systems}

Enterprise Resource Planning (ERP) systems are primarily characterized by modularity (Oghazi, Rad, Karlsson, \& Haftor, 2018). The system operates on one 
database for the entire organization. Thanks to this, the company has the ability to view and control the activities of the entire organization in one system.

A feature of this class of systems is its great flexibility when it comes to the complexity of the system. The system is implemented into an enterprise by purchasing a finished product license or designing a system for a given organization. In this case, the company has an impact on the choice of modules that it intends to use. The ERP system further improves the flow of information and cooperation of organizational departments. Thanks to the modularity, organization's subsystems can be based on information from other subsystems, which facilitates work and improves the efficiency and accuracy of decisions (Beheshti, Oghazi, Mostaghel, \& Hultman, 2014).

The ERP system gives even greater opportunities for partnership and cooperation with the organization's clients compared to its predecessors. It also provides the opportunity to introduce other management concepts, such as Just-In-Time, Quality Management and Lean Manufacturing. It also integrates all levels of organization management. The benefits of using ERP systems are also an increase in the efficiency of processes, not only production, but management of the entire enterprise, better ability to control and update data in the system and an increase in the level of reliability of the data received (Häkkinen \& Hilmola, 2008).

Using the ERP system involves the need to ensure its proper operation. Due to the high degree of complexity and capabilities that ERP provides, it is extremely important for the system to function properly in the organization. A system failure may result in temporarily stopping the business, which entails high costs (Soja, 2005).

However, many ERP systems lack a solution that would show production employees a specific number of products to perform for a given operation. This hinders the process of information exchange between production and the system, and thus the entire enterprise, because the information exchange takes too long. The problem appears primarily when the production plan is changed - in the event of a change in the ERP system there is a long delay before the information reaches the work stations. These problems are solved by the MES system - Manufacturing Execution System.

Manufacturing Execution System(MES) is a solution supporting the management of the production process at the operational level, i.e. it participates in the physical course of the process. The main goal of the MES system is to ensure the flow of information between the ongoing production and the planning department, and thus it is possible to optimize the production process throughout the enterprise (Bo, Zhenghang, \& Ying, 2004). Thanks to the MES system, it is possible to control the production process, redefine the process routings and decide when to start production and the possibility of improving the quality of product manufacture at lower costs, as well as increasing the level of customer service (McClellan, 1997; Valckenaers $\&$ van Brussel, 2005). The main source of information for the MES system is the 
planning taking place at ERP or MRPII system level (Pouraghabagher, 2013). The creation and development of MES systems began in the early 1980s, in parallel with the development of MRP II class systems (Oleśków-Szłapka \& Kudelska, 2012). The organization responsible for standardizing MES systems is MESA - Manufacturing Execution System Association.

The MES is primarily intended to support management at operational level. The MESA (the organization) has defined eleven tasks that the MES should fulfill (MESA, 1997; Oleśków-Szłapka \& Kudelska, 2012):

1) high quality workflow planning - planning a sequence of operations based on data flowing into the system,

2) management and monitoring of the company's production resources,

3) immediate response to events occurring during the production process and appropriate adjustment of work to the conditions,

4) providing company personnel with information on the production process,

5) registration of operational data available during the production process,

6) registration of the working time of the company's personnel,

7) analysis and quality management of manufactured products,

8) real-time monitoring of the production process and providing immediate information to the management level about the disruption of the production process,

9) maintenance in the production plant,

10) facilitating the identification of manufactured products at every stage of production,

11) providing data on the efficiency of the production process.

The implementation of the MES in the enterprise allows to obtain several benefits (Chen, 2006):

1) reduction of production costs,

2) reduction of production data registration time,

3) improving the quality of manufactured products,

4) increasing the speed of response to changes in market demand,

5) lowering the level of production inventory in progress,

6) reduction of inventory maintenance costs.

The MES as an addition to the ERP system requires changes at the organizational level in the enterprise. The IT department has more responsibilities due to the need to maintain more systems, while the planning department must support an additional system (Madapusi \& D'Souza, 2012).

The biggest problem in implementing the MES is its integration with the ERP system. Very often, enterprises have closed ERP systems, which means that they do not allow system configuration in accordance with user requirements. Another reason that hinders system integration is the provision of ERP and MES systems by separate organizations. The solutions may be incompatible with each other, which may cause difficulties in the case of system integration, or in extreme cases a lack of integration (Oman, Leskovar, Rosi, \& Baggia, 2017). 
Another problem in implementing the MES is integration with the machines owned by the company. This applies in particular to organizations that have outdated machinery. In such cases, the MES may not be possible to implement because the design of the machines may not allow data to be transferred to the system (Bernroider, Sudzina, \& Pucihar, 2011). The table below presents a comparison of the most important factors of the production process distinguishing between the ERP and MES systems.

Table 1. Comparison of the ERP and MES systems in the most important production process factors

\begin{tabular}{|l|l|l|}
\hline \multicolumn{1}{|c|}{ FACTOR } & \multicolumn{1}{|c|}{ ERP } & \multicolumn{1}{c|}{ MES } \\
\hline Distributing data & $\begin{array}{l}\text { Production data entered by office } \\
\text { workers }\end{array}$ & $\begin{array}{l}\text { Production data provided on an } \\
\text { ongoing basis }\end{array}$ \\
\hline $\begin{array}{l}\text { Machine visibility for the } \\
\text { system }\end{array}$ & Machines appear as an object & $\begin{array}{l}\text { Machines appear in the system as } \\
\text { a workstation }\end{array}$ \\
\hline $\begin{array}{l}\text { Possibility of ongoing moni- } \\
\text { toring of production }\end{array}$ & $\begin{array}{l}\text { No possibility of monitoring } \\
\text { current production }\end{array}$ & $\begin{array}{l}\text { Ongoing monitoring of production } \\
\text { is possible }\end{array}$ \\
\hline $\begin{array}{l}\text { Capability of production } \\
\text { planning }\end{array}$ & $\begin{array}{l}\text { Full production planning capabi- } \\
\text { lity - all required data is available }\end{array}$ & $\begin{array}{l}\text { Limited production planning } \\
\text { options }\end{array}$ \\
\hline Response to machine failure & $\begin{array}{l}\text { In the event of a machine failure } \\
\text { or downtime, the need for manual } \\
\text { registration in the system }\end{array}$ & $\begin{array}{l}\text { Machine failure or downtime re- } \\
\text { ported automatically to the system }\end{array}$ \\
\hline
\end{tabular}

Source: own study.

In the case of the ERP systems, the system supplier could allow to buy a special module that fulfills the tasks of the MES. However, if a manufacturing company is mainly interested in using the basic functionalities of the MES, i.e. ongoing monitoring of the production process and maintenance, one can use the functions available in the ERP Production Planning module.

Three factors can be distinguished as the basic differences between the MES and ERP systems. The first is the way data is collected. The MES collects real-time data from production, while the ERP class system shows reports based on data collected and entered by users after the production. Another difference is the functionality of the system. The MES is used to map the current situation during the production process and to control its course. The ERP system, in turn, is focused on production planning, quantitative analysis and production control after its completion. The final factor that differentiates the two systems is how the systems are linked to devices. The MES is configured with physical devices, while ERP has no connection to a specific machine. The ERP system is based on the exchange of data between systems in order to prepare reports and support the planning of relevant processes taking place in the enterprise (MESA, 1997; Oman et al., 2017). 


\section{The case study of implementing a solution}

The analysed company manufactures household goods. In the range of their products one can find many items that help maintain cleanliness at home as well as in the garden. The company focuses on the production of so-called "Small Household Appliances". Its range includes many products made of plastic, such as brooms, dishwashers, cloths, sponges and gloves. The company does not produce automatic appliances for large household equipment, such as washing machines and refrigerators.

Most products are sold in Poland, however the range produced by the company can also be found mostly Russia and Belarus, as well as Ukraine and Lithuania. In total, it has active sales of products to seventy-five countries around the world.

Only office employees have access to the ERP system. Each department can only use transactions assigned to a given module with which the department's work is related. Department managers are key users - they have more prerogatives than regular employees. The only access to the entire system is the IT department, which deals with maintenance, improvement and development, as well as correcting any errors in the system.

The solution was implemented in the examined enterprise on two machines. The implementation of the solution into the company's ERP test system and the configuration of appropriate tools took two weeks. Then, two workstations were selected on which the solution was tested. For another month, production workers were required to test the new solution, after prior training in its operation. During the tests the work was carried out both according to the old process flow so as not to disturb the production operation, and at the same time to test the new solution.

\section{Production processes and identification of problems in the organization of administrative support of the production process in the analysed company}

In this organization, the basis for starting production is to receive an order from the customer. Orders are accepted by the sales department, and data are entered into the ERP system, thanks to which it is possible to arrange production plans by the planning department.

The planning department deals with scheduling and determining the requirements for the components needed to carry out the production order. For this they use the ERP system, which contains all the necessary data to plan production launch. The planning department creates production orders in the ERP system for finished products and semi-finished products (if there is a need to produce them). Production orders are not released until all the components needed to start production are available. In their absence, the planning department reports the need for materials through the ERP system. These documents go to the purchasing department which then carries 
out the purchase order. If all components (or certainty of possession at the time of scheduled production start) are in place, the production orders are released. Then an employee from the planning department prints the production orders and sends them directly to the work stations dealing with the physical production of products. The operator of the workstation writes on this document the quantity of the product obtained during his/her shift, the number of errors and defective products, as well as any comments about production.

At the end of the shift, the workstation operator submits the production order documents to the appropriate place in the production hall. From there, they are taken by an employee from the planning department to create a summary of the change. The planner manually creates a spreadsheet file, entering all data for the planned production orders during a given shift in the plant.

Then the file is entered into the ERP system, reads data from the spreadsheet and, thanks to a specially dedicated program performing this operation, yield confirmations are entered into the system. Next, after performing quality control of the products, they are packed and sent to customers, and production orders are closed in the system. The sales department introduces the relevant documents into the ERP system, thanks to which it is possible to create an outbound delivery. At the end of the process, the finance department settles the costs associated with all the operations carried out during production and issues the appropriate accounting documents.

In the event of a breakdown at the workstation, the operator of the stand reports the issue to the manager of the production hall, who then creates an emergency notification in the ERP system, sent to the maintenance department. This department deals with diagnosing the failure and determining the necessary components to remove it. Then a repair order is created, on which all the components are listed and the appropriate service is ordered.

After the repairs are completed, the order is closed in the system. It is then also supplemented with data on the duration of the failure and possible production downtime. The costs incurred during the breakdown, such as service costs, components and costs of production downtime, are also recalculated. After closing the order, the finance department deals with the settlement of the failure order.

The company diagnosed several problems during the production process:

1) hand-delivery of orders to work positions by planning department employees,

2) filling in production orders on a sheet of paper by operators of work stations,

3) production staff have to provide production confirmation to the planning department employee before the end of the shift,

4) the planning department has to manually complete spreadsheets creating a production statement,

5) entering a spreadsheet into the ERP system takes a long time and often reduces system performance due to its size,

6) the need to print production orders. 
The first problem noticed during the production processes is the need to provide printed documents. An employee of the planning department has to leave his/her workplace to provide the documents needed for production, which negatively affects the focus and work efficiency.

Workstation operators reported the inconvenience of having to issue confirmation cards. Frequently they have to move away from their work station, and remove their protective clothing to be able to complete the document. The bigger problem for them is the need to provide production documents back to the planning department. The planning department has to put a lot of effort, due to the need to first place orders and then collect them at the end of the production shift. However, most work goes into the preparation of the summary spreadsheet file, based on all production order documents. This significantly extends the time of data processing and information exchange, and also generates much more work. The data implementation operation will also reduce the performance of the ERP system throughout the enterprise, which is the reason for unwanted breaks in work.

The need to enter data from the paper documents into a spreadsheet, and then into the ERP system takes up the time of the planning department. According to observations, this delay ranges from 1.5 to 3 days. Therefore, decision-makers are not able to plan material requirements and production on an ongoing basis.

Analysing the process of reporting a failure, a performance problem was also identified, associated with the need to report each failure of a workstation to the manager of the production hall. Managers complain that due to the need for a preliminary diagnosis they are unable to fully perform their other duties. They are often distracted from work, which does not positively affect their performance.

Another problem concerns the need to print production order documents planned for a given change. This generates unnecessary costs associated with the purchase of paper and printer toners, and causes the later need to destroy documents after entering the confirmations in the spreadsheet.

The management's idea for solving the efficiency problems of both processes was shifting some of the obligations to fill in data in the ERP system from management to production employees. Currently, workstation operators do not have access to the system. The only way to exchange information directly between them is by filling in production order cards and notifying managers of production machine failures. The solution would have to assume remote, and at the same time very limited, access to the ERP system. The only operations that would be available to operators of work stations would be the ability to directly report yield, and hence confirmations, as well as reporting failures to the maintenance department through the ERP system. Such a solution would reduce the information flow time, and also relieve office workers from unnecessary responsibilities. 


\section{Solution to the problems of administrative organization of production processes}

The solution to the analysed problems presented in the previous section is an app that allows access to selected functions in the system from a mobile device. The purpose of the application is to provide two-way and immediate communication between the workstation and the ERP system.

By sending messages to the system, the ERP administrator will be able to immediately approve the yield in the production system. Thanks to this solution, an employee can also report breakdowns of the machine he/she is currently working on. The solution also includes ready-made support reports in the ERP system, enabling administrators to easily and quickly process data.

The solution involves placing mobile devices at work stations (tablet or telephone with permanent internet access). After the work is done, the operator at the workstation, instead of filling in the product card, reports the yield directly to the ERP system using the mobile app.

The main advantage is direct access to data in the system from a mobile device. It allows faster preparation of the employee for work and a more transparent view of production orders at a given workstation. Thanks to this, it is no longer necessary to save the yield on paper cards by employees or manually calculate the total yield. At the same time, for administrators, it facilitates work on the final approval of production orders and maintenance of the workstation. Mobile devices are paired and assigned to the particular machine, so the operator can only see the production orders and operations which should be carried out on the particular machine.

The presented solution clearly shows who made and confirmed the yield. An additional advantage is the possibility to resume production of a given order if it is necessary to interrupt it. The app is able to show any employee activity while working on a given production order.

The solution has two main functions:

1. Handling production orders - review and reporting of yield:

Production employees have access to orders and their details, such as:

- what is the planned yield and what material is to be produced,

- the number of units currently being produced,

- the remaining number of units for generating the planned yield.

2. Reporting machine failure:

Another feature of the solution is the ability to send machine failure messages to the system. The employee makes a notification about the failure of the device on which he/she works. Thanks to a specially prepared report, administrators can immediately find out about the failure and intervene depending on the complexity of the problem. The report enables the transition to notification modification, where the administrator completes the notification with the necessary elements and finally confirms the notification in the system. 
In addition to standard messages, it is also possible to add one's own messages, which will be saved on the server, which can be read from a specially created report.

The app has a clear user interface. After opening the software, a screen with three tabs appears:

1) failures - a place where all failures are reported at the workplace,

2) messages - messages that appear in this tab have not been sent to the system for various reasons. If sending the message fails, the app does not delete it, it only displays the message in this tab so that after solving the problem one can resend the message without having to enter the parameters again,

3) orders - this tab shows all production orders assigned to a given workstation. After selecting a given order, its details are displayed.

The basic functionality of the app is the ability to immediately confirm the yield at the workplace. This information goes directly to the ERP system. As a response, the mobile app receives information about the success or error of saving data to the database.

The production orders are reviewed in the Orders tab. After switching to this tab, the user will be presented with a list of all production orders to be carried out at the given workstation. The data that is visible on the first screen includes: order number, the date and time when the order was created in the ERP system, the material to be processed together with the unit and the number of units to be processed. The user selects the given order from the list by holding the given data for a second. The Confirmation button appears on the screen, which must be clicked once to proceed.

The confirmation screen has seven fields that the user must complete:

1) confirmation time - date and time of the operation. The current time is set by default,

2) operation - the number of the operation at which the workstation operator worked,

3) type of confirmation - information important for the ERP system. The user determines whether he/she has performed the given operation for the entire order or for part of it,

4) machine - the work station at which the operator works. The field is filled in by default based on the assignment of the mobile device to the workstation,

5) description - the user has the option of entering comments regarding the production process carried out,

6) quantity produced - the number of units that have been processed by the user,

7) errors - the number of defective units that have arisen during the production process.

After completing the data, clicking the Save button at the bottom of the screen will trigger sending the message. After processing the data, the screen displays a message that the recording has been successfully completed. 
If a failure is noticed at the workstation, the operator of the workstation has the option of creating an emergency notification directly in the ERP system through the mobile app by going to the Failures tab and then clicking the Machine Failure option.

The screen used to enter the details of the failure will appear on the mobile device. After completing the fields, pressing the Save button will send the message to the ERP system. The system will return information about the success or write 'failure' to the device.

The data that is required to report a machine failure includes:

1) time of failure - date and time of the interference with the machine. By default, the field is filled in by the app with the current date and time,

2) action to be performed - the category of emergency notification. The user has the choice of failure notification, service request and machine activity report,

3) failure name - title or short description of the event,

4) machine - the name of the workstation to which the mobile device is assigned,

5) place of breakdown - place of the machinery and equipment structure where the breakdown occurred,

6) description of the failure - detailed description of the event.

Thanks to the use of this technology, it is possible to easily pair mobile devices with the ERP system. In this case, the need for further integration of machines with the other production system and having a highly advanced network infrastructure disappears. All the presented functions and application possibilities are included in standard ERP system solutions. The implementing the presented solution into the production process of the company excludes the need to introduce the MES if the company wants to use its basic functions, which is monitoring the process of yield and the possibility of better control and maintenance of the machinery and equipment.

\section{Conclusion}

The presented author's solution is in the phase of being introduced into the enterprise. The first trials of technology were successful and brought the intended effect. It was possible to enter the technology into the system, as well as correctly perform the configuration with the ERP version of the analysed company. They have been introduced to the testing phase on two work stations. The production workers who took part in the testing were positive about the changes. The planning department employees reacted very favourably to the introduced changes, because the solution of remote communication of the workstation with the ERP system facilitates their work by reducing the number of their duties.

The presented technology of expanding the ERP system is an opportunity for companies in the development and improvement of main production processes and maintenance. It allows to shorten information exchange times and to better distribute 
responsibilities among employees of the organization. Thanks to this solution, it is possible to achieve many benefits for enterprises that will allow for a better and easier way to manage the main sphere of economic activity, as well as save time and reduce the amount of costs arising during the organization's manufacturing activities.

The first advantage is that the company does not have to print production orders. This not only saves time, but also lowers operating costs. The most important improvement, however, is the lack of the need for the excessive involvement of the planning department in the exchange of information with the operators of workstations. Thanks to equipping workstations with mobile devices, they are able to check the number and details of production orders planned for a given workplace on an ongoing basis. Thus the planning department can focus more on further streamlining the production process by better planning the allocation of resources during subsequent production orders.

Thanks to the remote connection of mobile devices with the SAP ERP system server, production workers can directly enter production confirmations into the system. Operators no longer have to hand over order documents to the planning department, which improves their productivity in the workplace. However, the possibility of remote acknowledgments mainly enhances the comfort of the work of the planning department employees. It is no longer necessary to fill in a spreadsheet, which reduces the time of entering data into the system to a minimum. The only obligations of planners related to production orders remains the establishment and closing of production orders, as well as control of the number of confirmations entered into the SAP ERP system.

The presented solution also improves the problem noticed by the company's management during the maintenance process. The operator of the workstation can directly enter the failure notification into the system. This removes the obligation for the production hall manager to enter data. Thanks to this, he/she can take care of organising the work and supervising its course.

Thanks to the presented solution, the introduction of the basic functions of the MES class system allows for a better and faster response in the event of changes in production orders. This saves time and resources, as workstation operators have access to the list of orders on an ongoing basis. Additionally, management and the planning department are able to react faster to the occurrence of unexpected incidents during the execution of production work.

In the future, it is planned to fully introduce the solution to the analysed enterprise. The expected result of the introduction should be a significant reduction in operational costs, an increase in the quality of manufactured products and also in the level of customer service. The next implementation phases also assume the greater integration of the ERP system with the mobile app by adding new messages and sending more data from the system to the mobile device. 


\section{References}

Beheshti, H., Oghazi, P., Mostaghel, R., \& Hultman, M. (2014). Supply chain integration and firm performance: An empirical study of Swedish manufacturing firms. Competitiveness Review: An International Business Journal incorporating the Journal of Global Competitiveness, 24(1), 20-31.

Bernroider, E. W., Sudzina, F., \& Pucihar, A. (2011). Contrasting ERP absorption between the transition and developed economies from Central and Eastern Europe (CEE). Inf. Syst. Manag., 28(3), 240-257.

Bo, L., Zhenghang, C., \& Ying, C. (2004). Research on reconfigurable manufacturing execution system (Intelligent Mechatronics and Automation. Proceedings. International Conference on Intelligent Mechatronics and Automation, 2004, Chengdu, China, (pp. 157-161).

Chen, K. Y. (2006). Performance measurement of implementing manufacturing execution system. $M a-$ terials Science Forum, 505, 1117-1122.

Cupek, R., Ziębiński, A., Huczała, Ł., \& Erdogan, H. (2016). Agent-based manufacturing execution systems for short-series production scheduling. Computers in Industry, (82).

Hadaś, Ł., Fertsch, M., \& Cyplik, P. (2012). Planowanie i sterowanie produkcją. Poznań: Wydawnictwo Politechniki Poznańskiej.

Häkkinen, L., \& Hilmola, O.-P. (2008). ERP evaluation during the shakedown phase: Lessons from an after-sales division. Information Systems Journal, 18(1).

Lewis, M. (2019). Operations management: A research overview. Routledge.

Madapusi, A. \& D'Souza, D. (2012). The influence of ERP system implementation on the operational performance of an organization. International Journal of Information Managment, 32(1), 24-34.

McClellan, M. (1997). Applying manufacturing execution systems. Boca Raton, FL.: St. Lucie Press.

MESA. (1997). MES explained: A high level vision for executives. MESA White Paper, (06).

Meyer, H., Fuchs, F., \& Thiel, K. (2009). Manufacturing execution systems: Optimal design, planning, and deployment. New York: McGraw Hill.

Oghazi, P., Rad, F., Karlsson, S., \& Haftor, D. (2018). RFID and ERP systems in supply chain management. European Journal of Management and Business Economics, 27(2), 171-182

Oleśków-Szłapka, J., \& Kudelska, I. (2012). Informatyczne wspomaganie planowania i sterowania produkcją. Poznań: Wydawnictwo Politechniki Poznańskiej.

Oman, S., Leskovar, R., Rosi, B., \& Baggia, A. (2017). Integration of MES and ERP in supply chains: Effect assessment in the case of the automotive industry. Tehnicki Vjesnik, 24(6).

Pouraghabagher, R. (2013). Manufacturing Execution System (MES) an examination of implementation strategy (IIE Annual Conference and Expo).

Saenz de Ugarte, B., Artiba, A. \& Pellerin, R. (2009). Manufacturing execution system - a literature review. Production Planning \& Control - Production Planning Control, (20), 525-539.

Safra, I., Jebali, A., Jemai, Z., Bouchriha, H., \& Ghaffari, A. (2021). The beneficial effect of information sharing in the integrated production-distribution planning of textile and apparel supply chain. RAIRO - Operations Research, (55). doi: 10.1051/ro/2021038

Sardjono, W., Sudirwan, J., Priatna, W., \& Putra, G. (2021). Application of factor analysis method to support the users acceptance model of ERP systems implementation. Journal of Physics: Conference Series, (1836). doi: 012032. 10.1088/1742-6596/1836/1/012032

Sari, M., \& Santoso, B. (2021). Analysis of Enterprise Resource Planning (ERP) system implementation for manufacturing in Indonesia. Journal of Physics: Conference Series, (1823). doi: 012116. 10.1088/1742-6596/1823/1/012116.

Simunovic, G., Saric, T., \& Lujic, R. (2008). Application of neural networks in evaluation of technological time. Strojniski vestnik - Journal of Mechanical Engineering, 54(3), 179-188.

Soja, P. (2005). Rozwój zintegrowanych systemów zarządzania klasy ERP. Kraków: Katedra Informatyki, Akademia Ekonomiczna w Krakowie. 
Śliwczyński, B., Koliński, A., \& Andrzejczyk, P. (2014). Organizacja i monitorowanie procesów produkcyjnych. Poznań: Instytut Logistyki i Magazynowania.

Tsai, W.-H., Lan, S.-H., \& Lee, H.-L. (2020). Applying ERP and MES to implement the IFRS 8 operating segments: A steel group's activity-based standard costing production decision model. Sustainability, 12(10), 4303. doi: 10.3390/su12104303.

Tseng, M.-L., Wu, K.-J., \& Nguyen, T. (2011). Information technology in supply chain management: A case study. Procedia - Social and Behavioral Sciences, (25), 257-272. doi: 10.1016/j. sbspro.2011.10.546.

Valckenaers, P., \& van Brussel, H. (2005). Holonic manufacturing execution systems. CIRP Annals-Manufacturing Technology, 54(1), 427-432. 